\title{
Snake mortality and cover board effectiveness along exclusion fencing in British Columbia, Canada
}

\author{
Dana M. Eye ${ }^{1}$, Jared R. Maida ${ }^{1}$, Owain M. MCKibbin ${ }^{2}$, Karl W. Larsen ${ }^{3,}$, and Christine A. \\ BISHOP $^{4}$
}

\begin{abstract}
${ }^{1}$ Environmental Science Program, Thompson Rivers University, 805 TRU Way, Kamloops, British Columbia V2C 0C8 Canada
${ }^{2}$ Environment and Climate Change Canada, Canadian Wildlife Service, Protected Areas Unit, 5421 Robertson Road, Delta, British Columbia V4K 3N2 Canada

${ }^{3}$ Department of Natural Resource Science, Thompson Rivers University, 805 TRU Way, Kamloops, British Columbia V2C 0C8 Canada

${ }^{4}$ Environment and Climate Change Canada, Science and Technology Branch, Wildlife Research Division, 5421 Robertson Road, Delta, British Columbia V4K 3N2 Canada

${ }^{*}$ Corresponding author: klarsen@tru.ca
\end{abstract}

Eye, D.M., J.R. Maida, O.M. McKibbin, K.W. Larsen, and C.A. Bishop. 2018. Snake mortality and cover board effectiveness along exclusion fencing in British Columbia, Canada. Canadian Field-Naturalist 132(1): 30-35. https://doi.org/10.226 21/cfn.v132i1.2031

\begin{abstract}
We report on snake mortalities along exclusion fencing in southern British Columbia, showing Western Yellow-bellied Racer (Coluber constrictor mormon) deaths were disproportionately higher than our encounter rates with the species within the snake community. This suggests racers were susceptible to fence mortality more so than Northern Pacific Rattlesnakes (Crotalus o. oreganus) or Great Basin Gophersnakes (Pituouphis catenifer deserticola). Datalogger recordings revealed temperatures under cover boards were well above the tolerable temperatures of the three snake species, although the boards appeared to temper ambient heat more efficiently than natural vegetation. We caution that the effects of fencing and cover boards may vary across ecosystems and snake species.
\end{abstract}

Key words: Coluber; conservation; Crotalus; Great Basin Gophersnake; Northern Pacific Rattlesnake; Pituophis; reptiles; Western Yellow-bellied Racer

\section{Introduction}

Human disturbance imposes drastic changes upon natural environments, often with severe consequences for wildlife populations. Two such effects are barriers to movement, and increasing human-wildlife interactions (Colley et al. 2017; Markle et al. 2017; Pitts et al. 2017). Managers often employ multiple techniques to mitigate negative human-wildlife conflicts. Historically, wildlife fencing is considered an efficient approach for limiting wildlife movement. Most notably, it has been used to reduce road mortality of large macrofauna (Peaden et al. 2017) but has also been widely used for herpetofauna (Colley et al. 2017; Markle et al. 2017).

In general, there are two major fence types used to direct the movements of herpetofauna: drift and exclusion. Drift fences are long continuous barriers used to channel animal movement, often for research purposes by adapting them to trap animals (Willson and Gibbons 2009). Conversely, exclusion fences eliminate animal access to a specific area such as roadways and areas with high human influence (Markle et al. 2017).

Exclusion fencing can be an important conservation tool to promote spatial separation between humans and animals that pose a risk, such as venomous snakes. Historical efforts to limit and manage negative snake-human interactions often have included the relocation of animals. However, this strategy has limitations and potential negative consequences on the translocated snakes (Reinert and Rupert 1999; Nowak et al. 2002; Brown et al. 2009). More recently, fencing has been used to target snakes and other reptiles to limit road mortality and restrict animal movement through various urban settings (Colley et al. 2017; Markle et al. 2017).

Although sometimes effective, wildlife fences pose potential problems to snakes and other reptiles such as restricting movements or otherwise altering behaviour (Markle et al. 2017; Peaden et al. 2017). For example, Mohave Desert Tortoises (Gopherus agassizii) that encountered roadside fencing had extreme carapace temperatures that approached the species' tolerance limits and exhibited greater movement velocity compared to individuals away from fencing structures (Peaden et al. 2017). Furthermore, Wilson and Topham (2009) found that fencing caused road mortality by preventing Tiger Whiptail lizards (Aspidoscelis tigris) from retreating from the danger posed by roads. In Australia, Eastern Long-necked Turtle (Chelodina longicollis) mortalities (mainly due to overheating) were observed along a pest-exclusion fence, with animals showing signs of sunburn and predation (Ferronato et al. 2014). Despite 
these examples of varying fence effects, the potential direct and indirect negative effects that fencing has on herpetofauna is still largely unknown and understudied, particularly for snakes.

Here we outline observations on the impacts of mitigative exclusion fencing on a snake community in arid southern British Columbia. We compare observations and counts of live and dead snakes detected near the fence, and also report on the use of wooden cover boards as putative thermal refugia for snakes moving along the fencing structure in the hot, open desert habitat.

\section{Methods}

Our study site was located on the Osoyoos Indian Reserve (OIR) near the town of Osoyoos $\left(49.03^{\circ} \mathrm{N}\right.$, $119.47^{\circ} \mathrm{W}$ ) in the south Okanagan Valley of British Columbia (BC). The 450 ha study area contains a dry, arid ecosystem composed of shrub-steppe habitat dominated by Antelope-brush (Purshia tridentata (Pursh) de Candolle) and Big Sagebrush (Artemisia tridentata Nuttall). Mean summer (June, July, August) air temperature in Osoyoos and surrounding south Okanagan Valley is approximately $22^{\circ} \mathrm{C}$. However, summer mean maximum temperatures can be as high as $33^{\circ} \mathrm{C}$ and extreme maximum temperatures will exceed $40^{\circ} \mathrm{C}$ (Environment Canada 2017), making this one of Canada's hottest regions. The study site has been, and continues to be, heavily altered as the landscape shifts towards tourism development including golf courses, vineyards, a resort and campground, and associated roads and parking lots. The study site is home to a long-term snake research project targetting three species-at-risk, Northern Pacific Rattlesnake (Crotaus o. oreganus), Great Basin Gophersnake (Pituophis catenifer deserticola), and Western Yellow-bellied Racer (Coluber constrictor mormon). Both this rattlesnake and gophersnake are listed as threatened species in Canada (SARA Registry 2018a,b) and the racer has been recommended for listing as threatened (COSEWIC 2015). For additional description of the region and the study site, see Brown et al. (2009) and Lomas et al. (2015).

In an attempt to mitigate negative human-snake conflict, $\sim 4 \mathrm{~km}$ of exclusion fencing was built in 2006 to separate natural snake habitat from the high human traffic and popular tourist areas. The fence was constructed of $\sim 60 \mathrm{~cm}$ high galvanized mesh hardware cloth with $\sim 0.60 \mathrm{~cm}$ square openings and ran approximately north-south through the study area. In 2006, during initial construction of the fence, snake mortalities were observed along a newly constructed section of the fence (one neonate rattlesnake and six racers; O.M.M. pers. obs.). These early observations suggested that snakes may have been dying from exposure to daytime heat while attempting to navigate the new physical barrier.

In 2007 we investigated if the construction of artificial cover, in the form of wooden cover boards, would create appropriate thermal refuge habitat for snakes moving along the new fence structure. Twelve sets of triplet plywood cover boards $(70 \mathrm{~cm} \times 70 \mathrm{~cm} \times 7 \mathrm{~cm})$ were placed along the exclusion fence at $30 \mathrm{~m}$ intervals (equalling $360 \mathrm{~m}$ of the fencing structure), in the area where snake mortalities had been observed the previous year. At each interval, two of the three boards were placed on opposite sides of the fence and the third board was placed $10-15 \mathrm{~m}$ east of the fence in the natural habitat as a control. Each cover board was raised approximately $7 \mathrm{~cm}$ off the ground by wooden edge pieces, and $15-20 \mathrm{~cm}$ of sand was excavated under the centre of each board to ensure access for both large and small reptiles.

Dataloggers (DS1921G Thermochron ${ }^{\circledR}$ iButton $\AA$; Baulkham Hills, New South Wales, Australia) were used to record temperature data every hour between May and October 2007. The dataloggers were placed under fence $(n=10)$ and control $(n=6)$ cover boards, and under natural vegetation typically favoured by snakes (Big Sagebrush, Rubber Rabbitbrush [Ericameria nauseosa (Pallas ex Pursh) G.L. Nesom \& G.I. Baird], Antelope-brush; $n=5$ ). We placed an additional datalogger fully exposed on the open ground to collect additional reference data. Furthermore, throughout the course of the 2007 summer field season, we monitored and observed the cover boards for snake use. We compared the average maximum daily temperature (typically 1400-1600 h) between the different treatments throughout July 2007. We chose to focus on July because it typically constitutes the hottest month of the active season in the Okanagan Valley (Environment Canada 2017) when refuge from the heat would be critical.

In 2015, major upgrades along the fence were performed, including repair work, vegetation control, and re-routing approximately $200 \mathrm{~m}$ to avoid erosion. This marked the first major, large-scale upgrade to the entire fence structure since its original construction. Over the next two years (2016-2017), fence surveys (walking fence line) were initiated approximately $2-3$ times a week between May and October to detect snakes and monitor fence effectiveness. In addition to the fence surveys, we conducted mark-recapture surveys almost daily (5-6 days per week) throughout the entire study area. We captured and marked live-snakes with Passive Integrated Transponders (PIT tags - HPT12 Pre-load; Biomark Inc., Boise, Idaho, USA) to allow for individual recognition in subsequent captures.

\section{Results}

Temperature differences between the fence cover boards and control cover boards appeared to stay relatively consistent throughout July, and cover boards had lower average maximum daily temperatures than the native vegetation cover or areas with no cover (Figure 1). Maximum daily temperatures during midsummer (July) routinely surpassed $35^{\circ} \mathrm{C}$ at all of our 


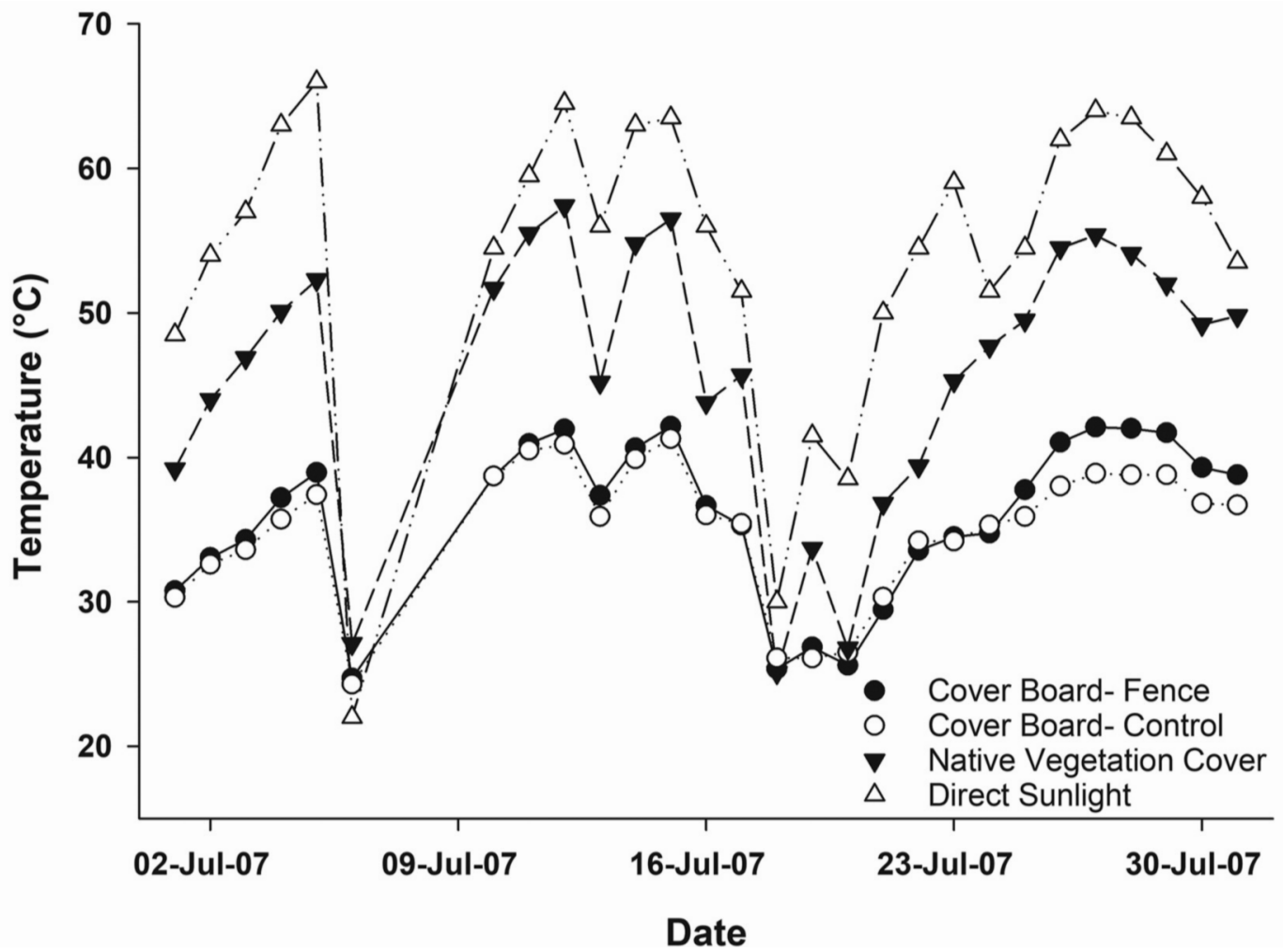

FIGURE 1. Daily mean maximum temperatures of fence $(n=10)$ and control $(n=6)$ cover boards, natural vegetation cover $(n=5)$ and exposed ground $(n=1)$ in July 2007 on the south Okanagan Valley study site, near Osoyoos, British Columbia.

recording sites (including under cover boards), and temperatures under native vegetation cover occurred in excess of $50^{\circ} \mathrm{C}$. We found nine rattlesnakes under cover boards along the fence over the course of the entire 2007 active season.

During the 2016 and 2017 field seasons (following fence upgrading), 341 snakes were captured throughout the entire study area during ongoing mark-recapture and monitoring of the snake community. Specifically, counts of the three main species in the area were 215 rattlesnakes, 62 gophersnakes, and 64 racers. During this same time, we captured 116 live snakes (59 rattlesnakes; 23 gophersnakes; 34 racers; Figure 2) directly along the same section of fence earlier used for the cover board study; however, no snakes were captured under cover boards. We also observed 15 snake mortalities directly along the same fence section (two rattlesnakes; one gophersnake; 12 racers). Additionally, we found six of the 15 dead snakes (one rattlesnake, one gophersnake and four racers) within the section of fence that was added in 2015. We found all snake mortalities along the exclusion fence in the open rather than beneath cover boards. In total, fence mortalities appeared responsible for $33 \%(15 / 45)$ of snake mortality observations throughout our study site during the 2016 and
2017 field seasons (roadkill $=49 \%$, unknown and/or natural mortality $=18 \%$ ).

The relative proportions of the three snake species within the sample of fence captures differed significantly (R Core Team 2016) from recorded captures over the larger study area $\left(\chi_{2}^{2}=9.4, P<0.01\right)$. At the same time, the relative proportions of dead snakes observed along the fence differed significantly from both live snakes captured near the fence $\left(\chi^{2}{ }_{2}=18.9, P<0.01\right)$ and from those in the general population $\left(\chi^{2}{ }_{2}=36.3\right.$, $P<0.01)$. In all cases, racers were over-represented in the fence mortality data set, and rattlesnakes underrepresented (Figure 2).

\section{Discussion}

Although using cover boards to monitor snakes and other herpetofauna is a common and efficient practice (Reading 1997; Engelstof and Ovaska 2000; Halliday and Blouin-Demers 2015), they appeared to be underused by snakes in our study area, as we only observed nine rattlesnakes (no gophersnakes or racers) under cover boards during an entire active summer season. For snakes and other reptiles, thermal requirements while balancing predator avoidance are key drivers of microhabitat selection (Downes 2001; Lelièvre et al. 


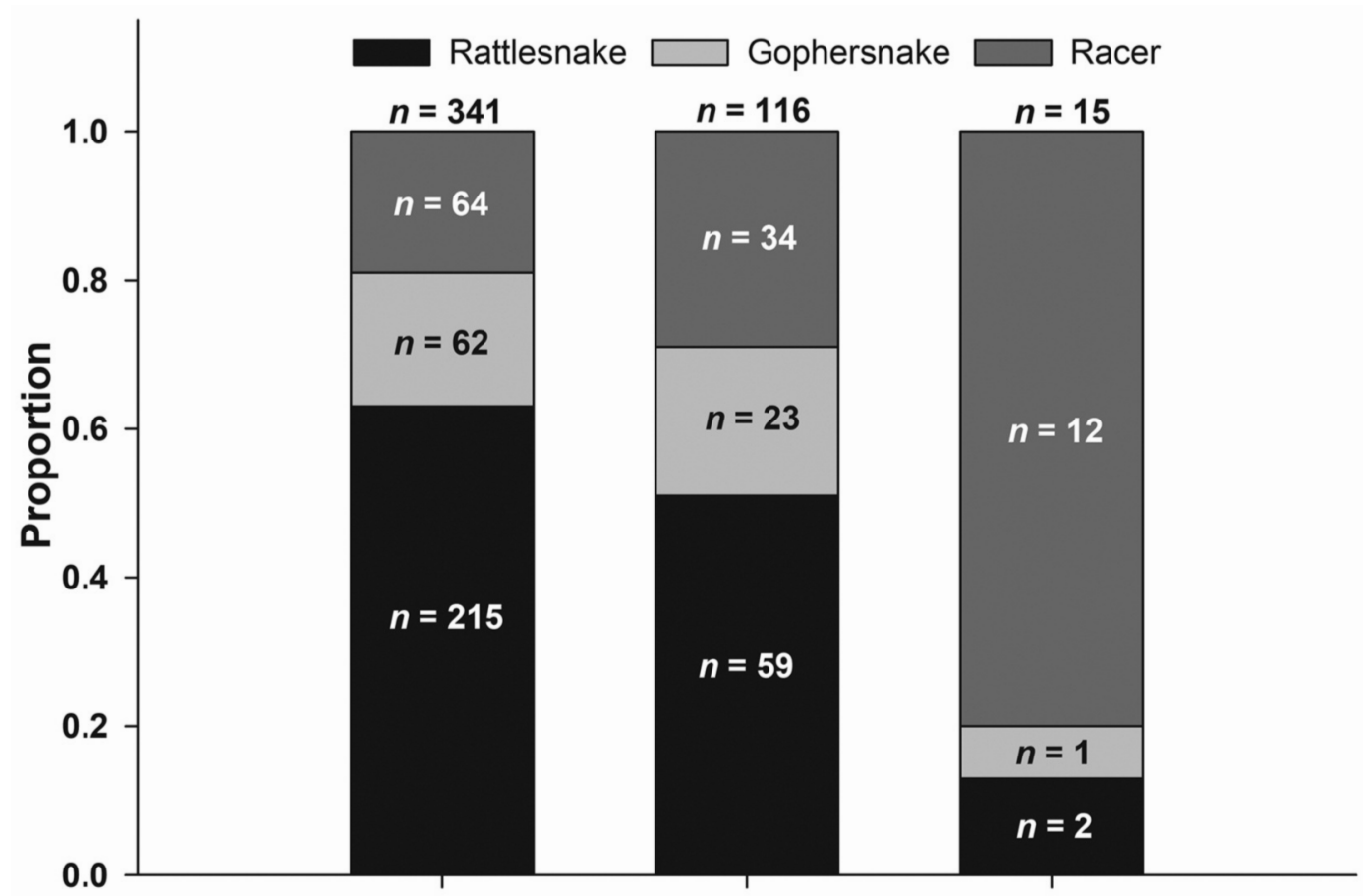

\section{Marked population Fence captures Fence mortalities}

FIGURE 2. Total sample sizes and proportion comparisons of Northern Pacific Rattlesnake (Crotalus o. oreganus), Great Basin Gophersnake (Pituophis catenifer deserticola), and Western Yellow-bellied Racer (Coluber constrictor mormon) marked populations, fence captures, and fence mortality observations during the 2016 and 2017 field seasons at the south Okanagan Valley study site, near Osoyoos, British Columbia.

2010). Based on our capture rates, individual snakes appeared not to be using these cover board 'habitats' heavily during the peak summer season, likely because the high temperatures under the boards negated any benefit in terms of potential predator avoidance or thermal refuge. Average daily maximum temperatures during July under the cover boards were typically far higher than the preferred body temperatures and critical maxima reported for rattlesnakes $\left(28.9^{\circ} \mathrm{C}\right.$ versus 39 $40^{\circ} \mathrm{C}$ ), gophersnakes $\left(26.7^{\circ} \mathrm{C}\right.$ versus $40.5^{\circ} \mathrm{C}$ ), and racers $\left(28.3^{\circ} \mathrm{C}\right.$ versus $42.4^{\circ} \mathrm{C}$; Brattstrom 1965; Putman and Clark 2017; Figure 1). We acknowledge that operative body temperatures of snakes often may vary from ambient air temperature (Blouin-Demers and Weatherhead 2001), and direct comparisons between air temperature and preferred snake body temperature may be, in some cases, questionable. However, the degree to which our recordings surpassed the published tolerance levels for these snakes strongly suggests the boards would have represented inappropriate microhabitat.

In comparison, average daily maximum temperatures in July under the cover boards were cooler than those recorded under the local native vegetation. This may imply that effective refuge sites (e.g., large rock formations, deep holes) during the peak summer heat may be critical, at least in this particular ecosystem. Modifications to these cover boards would appear necessary for creating suitable thermal refuge habitat for snakes during the height of summer at our study site. Examples of possible modifications include increasing the overall size of the plywood structure (Halliday and Blouin-Demers 2015), applying a coating to the outer surface of the cover board specifically to reflect solar radiation (Synnefa et al. 2005), and/or increasing the insulation under the cover boards through pits or underground chambers (C.A.B. and K.W.L. pers. obs.).

Racer mortalities along the fence were proportionally over-represented compared to our overall captures of snakes in the community, strongly suggesting these animals were predisposed to dying near the fence more so than the other two species. The impact of exclusion fencing may be greater for agile and highly active snakes. Species that are relatively active and/or undergo longer migrations may be more likely to encounter fences and other disturbances, potentially becoming isolated from crucial resources (Ferronato et al. 2014; Martin et al. 2017). Home range and movement data for Western Yellow-bellied Racer in BC are scant, but Brown and Parker (1976) showed home ranges for 
this species in Utah generally extended no further than $1000 \mathrm{~m}$ from den sites. In the Okanagan Valley, the average maximum distance gophersnakes disperse from their dens is $520 \mathrm{~m}$ (10.5 ha home range: Williams et al. 2012) and rattlesnakes in our study area move an average of $1082 \mathrm{~m}$ (25.1 ha home range) from their den location (Brown et al. 2009). In the south Okanagan Valley, racers are considered the most diurnally-active species with higher levels of activity, exposure and heat tolerance than other species (Brattstrom 1965; Ernst and Barbour 1989; COSEWIC 2015). Possibly a predilection for movement during the daytime renders racers relatively vulnerable to overheating and other lethal effects experienced while navigating fences and other obstacles.

Sudden increased mortality during the 2016-2017 field seasons could be due to several factors, such as the lack of direct surveying in the past (monitoring is time consuming and requires many working hours), or it may be correlated with fence upgrades that rendered the structure more impermeable to snakes. The specific section of the fence where snake mortalities were observed runs parallel to a lake (to exclude snakes from a large campground), restricting access to riparian habitat for those seeking to rehydrate, hunt, and avoid periods of extreme heat.

Following the new 200-m addition to the fence, we detected relatively more dead snakes along that section than elsewhere in our study site. The six snakes ( $40 \%$ of fence mortalities) found dead within a 20 $30 \mathrm{~m}$ section of the newly constructed section are of particular interest. These observations, along with the six dead snakes originally observed during initial fence construction in 2006, may suggest new exclusion fencing poses accentuated problems for snakes in the short term. However, without better knowledge on the factors driving snake migration and movements, it is difficult to determine why fencing and changes to fencing structures would increase mortality rates. Additionally, further investigation, long-term monitoring, and more detailed analysis are required to determine potential population-level impacts these fence mortalities are actually having in our study area.

Exclusion fencing has become a common strategy to mitigate human-reptile conflict and can be extremely effective; however, it is clear with our findings that the use of exclusion fencing is not without concern. The broader effects of exclusion fencing need to be investigated further to fully understand the implications and perhaps consequences to animals such as snakes. Similar to concerns raised for reptiles in other hot, dry regions (Ferronato et al. 2014; Peaden et al. 2017), there appears to be potential negative consequences for snakes encountering fencing in our study area.

\section{Author Contributions}

Writing - Original Draft Preparation: D.M.E. and J.R.M.; Writing - Review and Editing: D.M.E., J.R.M.,
K.W.L., and C.A.B.; Formal Analysis: D.M.E. and J.R.M.; Funding Acquisition: K.W.L. and C.A.B.; Investigation: D.M.E., J.R.M., and O.M.M.; Methodology: D.M.E, J.R.M, O.M.M, and K.W.L.; Supervision: K.W.L and C.A.B.

\section{Acknowledgements}

We would like to recognize C. Stringam and M. Holm for their unwavering support and logistical contributions to the project. We thank the Nk'Mip Desert Cultural Centre for providing laboratory and office space, and the Osoyoos Indian Band for granting us access to an exceptional study site and for their continued support of rattlesnake conservation and public education. We also thank J. Herbert, field assistants, and many Osoyoos Indian Band interns who helped with the initial construction and maintenance of the snake exclusion fencing and surveying.

\section{Literature Cited}

Blouin-Demers, G., and P.J. Weatherhead. 2001. Thermal ecology of Black Rat Snakes (Elaphe obsoleta) in a thermally challenging environment. Ecology 82: 3025-3043. https://doi.org/10.2307/2679832

Brattstrom, B.H. 1965. Body temperatures of reptiles. American Midland Naturalist 73: 376-422. https://doi.org/10. $2307 / 2423461$

Brown, S.B., and W.S. Parker. 1976. Movement ecology of Coluber constrictor near communal hibernacula. Copeia 1976: 225-242. https://doi.org/10.2307/1443941

Brown, J.R., C.A. Bishop, and R.J. Brooks. 2009. Effectiveness of short-distance translocation and its effects on Western Rattlesnakes. Journal of Wildlife Management 73: 419-425. https://doi.org/10.2193/2007-558

Colley, M., S.C. Lougheed, K. Otterbein, and J.D. Litzgus. 2017. Mitigation reduces road mortality of a threatened rattlesnake. Wildlife Research 44: 48-59. https://doi.org/10. 1071/WR16130

COSEWIC (Commmittee on the Status of Endangered Wildlife in Canada). 2015. COSEWIC assessment and status report on the Eastern Yellow-bellied Racer Coluber constrictor flaviventris and Western Yellow-Bellied Racer Coluber constrictor mormon in Canada. COSEWIC, Ottawa, Ontario, Canada. Accessed 15 December 2017. http:// sararegistry.gc.ca/document/default_e.cfm?documentID= 653.

Downes, S. 2001. Trading heat and food for safety: costs of predator avoidance in a lizard. Ecology 82: 2870-2881. https://doi.org/10.2307/2679967

Engelstoft, C., and K.E. Ovaska. 2000. Artificial coverobjects as a method for sampling snakes (Contina tenuis and Thamnophis spp.) in British Columbia. Northwestern Naturalist 81: 35-43. https://doi.org/10.2307/3536898

Environment Canada. 2017. National Climate Data and Information Archive. Environment Canada. Accessed 15 December 2017. http://www.climate.weatheroffice.gc.ca.

Ernst, C.H., and R.W. Barbour. 1989. Snakes of Eastern North America. George Mason University Press, Fairfax, Virginia, USA.

Ferronato, B.O., J.H. Roe, and A. Georges. 2014. Reptile bycatch in a pest-exclusion fence established for wildlife reintroductions. Journal for Nature Conservation 22: 577585. https://doi.org/10.1016/j.jnc.2014.08.014 
Halliday, W., and G. Blouin-Demers. 2015. Efficacy of coverboards for sampling small northern snakes. Herpetology Notes 8: 309-314.

Lelièvre, H., G. Blouin-Demers, X. Bonnet, and O. Lourdais. 2010. Thermal benefits of artificial shelters in snakes: a radiotelemetric study of two sympatric colubrids. Journal of Thermal Biology 35: 324-331. https://doi.org/10.10 16/j.jtherbio.2010.06.011

Lomas, E., K.W. Larsen, and C.A. Bishop. 2015. Persistence of Northern Pacific Rattlesnakes masks the impact of human disturbance on weight and body condition. Animal Conservation 18: 548-556. https://doi.org/10.1111/acv.12 208

Markle, C.E., S.D. Gillingwater, R. Levick, and P. ChowFraser. 2017. The true cost of partial fencing: evaluating strategies to reduce reptile road mortality. Wildlife Society Bulletin 41: 342-350. https://doi.org/10.1002/wsb.767

Martin, A.E., D. Jorgensen, and C.C. Gates. 2017. Costs and benefits of straight versus tortuous migration paths for Prairie Rattlesnakes (Crotalus viridis viridis) in seminatural and human-dominated landscapes. Canadian Journal of Zoology 95: 921-928. https://doi.org/10.1139/cjz2017-0031

Nowak, E.M., T. Hare, and J. McNally. 2002. Management of "nuisance" vipers: effects of translocation on Western Diamond-backed Rattlesnakes (Crotalus atrox). Pages 533560 in Biology of the Vipers. Edited by G.W. Schuett, M. Höggren, M. Douglas, and H. Greene. Eagle Mountain Publishing, Eagle Mountain, Utah, USA.

Peaden, J.M., A.J. Nowakowski, T.D. Tuberville, and K.A. Buhlmann. 2017. Effects of roads and roadside fencing on movements, space, use, and carapace length of a threatened tortoise. Biological Conservation 214: 13-22. https://doi. org/10.1016/j.biocon.2017.07.022

Pitts, S.L., B.D. Hughes, and I. Mali. 2017. Rattlesnake nuisance removals and urban expansion in Phoenix, Arizona. Western North American Naturalist 77: 309-316. https://doi.org/10.3398/064.077.0304

Putman, B.J., and R.W. Clark. 2017. Behavioral thermal tolerances of free-ranging rattlesnakes (Crotalus oreganus) during the summer foraging season. Journal of Thermal
Biology 65: 8-15. https://doi.org/10.1016/j.jtherbio.2017. 01.012

R Core Team. 2016. R: a language and environment for statistical computing. R Foundation for Statistical Computing, Vienna, Austria.

Reading, C.J. 1997. A proposed standard method for surveying reptiles on dry lowland heath. Journal of Applied Ecology 34: 1057-1069. https://doi.org/10.2307/2405294

Reinert, H.K., and R.R. Rupert, Jr. 1999. Impacts of translocation on behavior and survival of Timber Rattlesnakes, Crotalus horridus. Journal of Herpetology 33: 45-61. https: //doi.org/10.2307/1565542

SARA (Species at Risk Act) Registry. 2018a. Species profile: Western Rattlesnake. Accessed 4 April 2018. http://www. registrelep-sararegistry.gc.ca/species/speciesDetails_e.cfm ?sid $=808$.

SARA (Species at Risk Act) Registry. 2018b. Species profile: Great Basin Gophersnake. Accessed 4 April 2018. http:// www.registrelep-sararegistry.gc.ca/species/speciesDetails_ e.cfm?sid=722.

Synnefa, A., M. Santamouris, and I. Livada. 2005. A study of the thermal performance of reflective coatings for the urban environment. Solar Energy 80: 968-981. https://doi. org/10.1016/j.solener.2005.08.005

Williams, K.E., K.E. Hodges, and C.A. Bishop. 2012. Small reserves around hibernation sites may not adequately protect mobile snakes: the example of Great Basin Gophersnakes (Pituophis catenifer deserticola) in British Columbia. Canadian Journal of Zoology 90: 304-312. https://doi. org/10.1139/Z11-136

Willson, J.D., and J.W. Gibbons. 2009. Drift fences, coverboards, and other traps. Pages 229-245 in Amphibian Ecology and Conservation: A Handbook of Techniques. Edited by K.C. Dodd, Jr. Oxford University Press, New York, New York, USA.

Wilson, J.S., and S. Topham. 2009. The negative effects of barrier fencing on the Desert Tortoise (Gopherus agassizii) and non-target species: is there room for improvement? Contemporary Herpetology 3: 1-4.

Received 10 January 2018

Accepted 12 March 2018 